\title{
Growth of seven perennial plant species adapted to the Brazilian Semi-Arid
}

\author{
Paulo Sérgio Lima e Silva ${ }^{1,4}$, Kathia Maria Barbosa e Silva ${ }^{2}$, Raimundo Nonato Braga Lôbo ${ }^{3}$ and \\ Paulo Igor Barbosa e Silva ${ }^{1}$
}

Received: November 7, 2006. Accepted: March 29, 2007

\begin{abstract}
RESUMO - (Crescimento de sete espécies vegetais perenes adaptadas ao Semi-Árido brasileiro). A mensuração da altura da planta (y) e do diâmetro da copa $(\mathrm{x})$ em árvores pode não ser tarefa fácil, mas o diâmetro do caule (z) pode ser avaliado mais facilmente. Este trabalho teve por objetivos avaliar o crescimento de espécies adaptadas ao Semi-Árido brasileiro, nos primeiros dois anos de idade, e obter equações lineares para estimar y e x a partir de z, nessas espécies. Utilizou-se o delineamento de blocos ao acaso com quatro repetições. Os valores de x, z e y foram medidos semestralmente de outubro/2003 a março/2005. Prosopis juliflora e Mimosa caesalpiniaefolia apresentaram os maiores diâmetros do caule e altura da planta, respectivamente, e ambas apresentaram o maior diâmetro da copa. Nas equações para estimar a altura da planta a partir do diâmetro do caule, o valor do coeficiente de determinação $\left(R^{2}\right)$ variou de 0,76 (Tamarindus indica and Leucaena leucocephala) a 0,92 (Prosopis juliflora and Azadirachta indica). Nas equações que permitiram estimar o diâmetro da copa a partir do diâmetro do caule, o valor de $R^{2}$ variou de 0,70 (Leucaena leucocephala) a 0,92 (Azadirachta indica).
\end{abstract}

Palavras-chave: Altura da planta, análise de regressão, Caatinga, diâmetro do caule, diâmetro da copa

\begin{abstract}
Growth of seven perennial plant species adapted to the Brazilian Semi-Arid). Measuring plant height (y) and canopy diameter (x) in trees may not be an easy task, but stem diameter (z) can be more easily evaluated. This work's objective was two-fold: evaluate the growth of species adapted to the Brazilian Semi-Arid Region in the first two years of age, and obtain linear equations to estimate $\mathrm{y}$ and $\mathrm{x}$ from $\mathrm{z}$, in those species. A random block design with four replications was employed. The values for $\mathrm{x}, \mathrm{z}$, and $\mathrm{y}$ were measured biannually from October/2003 to March/2005. Prosopis juliflora and Mimosa caesalpiniaefolia showed the highest stem diameter and plant height values, respectively, and both showed the highest canopy diameter. In the equations to estimate plant height from the stem diameter the value of the coefficient of determination $\left(R^{2}\right)$ ranged from 0.76 (Tamarindus indica and Leucaena leucocephala) to 0.92 (Prosopis juliflora and Azadirachta indica). In the equations that allowed to estimate the crown diameter from the stem diameter the $R^{2}$ value ranged from 0.70 (Leucaena leucocephala) to 0.92 (Azadirachta indica).
\end{abstract}

Key words: Caatinga, canopy diameter, plant height, regression analysis, stem diameter

\section{Introduction}

The Semi-Arid Region of Northeastern Brazil covers an estimated area which represents nearly $10 \%$ of the Brazilian territory. The main vegetation type is deciduous thorn forest or thor bush savanna known as Caatinga (Sampaio et al. 1995). A typical ecosystem from the Northeastern region of Brazil, classified as top priority for preservation projects in Latin America and the Caribbean Islands, the Caatinga is a unique biome in the world. It encompasses a 800 thousand $\mathrm{km}^{2}$ area, including the States of the Northeastern region of Brazil, in addition to the northern part of the
State of Minas Gerais, harboring $29 \%$ of its whole population and $50 \%$ of the Brazilian rural population. The complex formed by the Caatinga and surrounding ecosystems has a significant floristic diversity, containing approximately 20 thousand plant species (Brasil 2001).

Despite its importance for mankind, the Caatinga region of Brazil is seriously threatened by desertification, at the same time that an increase in productivity is required to provide support to a growing population in search of development. The reasons for the desertification of the Caatinga are not different from those normally found in other areas of the world

\footnotetext{
${ }^{1}$ Universidade Federal Rural do Semi-Árido, Departamento de Ciências Vegetais, BR 110, km 47, C. Postal 137, 59625-900 Mossoró, RN, Brazil

2 Universidade do Estado do Rio Grande do Norte, Departamento de Ciências Biológicas, BR-110, km 48, Rua Antônio Campos s.n., C. Postal 70, 59610-090 Mossoró, RN, Brazil (kmbsbarbosa@yahoo.com.br)

3 Centro Nacional de Pesquisa de Caprinos, Fazenda Três Lagoas, Estrada Sobral Groaíras, km 4, C. Postal D10, 62011-970 Sobral, CE, Brazil (chpd@cnpc.embrapa.br)

${ }^{4}$ Corresponding Author: paulosergio@ufersa.edu.br
} 
(Cervantes et al. 1998). Almost always they are the result of inadequate utilization of resources, inappropriate practices in the use of resources, and, particularly, shortsighted models for regional development (Brasil 2001). Forest resources are usually the first to be exploited, because their products provide important income supplementation, and are also a source of primary energy (Francelino et al. 2003). Consequently, there is interest in evaluating the behavior of native species aiming at reforestation projects, the adoption of agroforestry systems, and even the cultivation of these species to preserve the Caatinga. It is interesting to include exotic species adapted to the Caatinga in this evaluation, since some of these species offer products that are not found in native species, such as neem, which is generating great interest among growers, researchers, and landscapers in the Brazilian northeast. Similar evaluations were carried out by other authors (Cervantes et al. 1998; Kumar et al. 1998; Deans et al. 2003), including at semi-arid regions (Abebe 1994).

Plant height is an important trait of forest species under several aspects, including species succession (larger trees can disperse their propagules more easily and enjoy a reproductive advantage), forest measurements (height is used as a spacing indicator), and environmental suitability (relations such as height/ age can be used as quality indicators for the area) (Leary et al. 1997). The canopy of trees is much less frequently evaluated than their respective stems, probably due to their smaller economic value. Notwithstanding, due to the fact that canopy size is closely related to its photosynthetic capacity, it is an important parameter in individual tree growth studies. It is also important in studies on the growth of plant groups due to the close correlations between canopy size and stem diameter and between canopy size and planting density (Hemery et al. 2005).

Measuring plant height and canopy diameter in trees may not be an easy task, but stem diameter can be more easily evaluated. Thus, one idea would be to estimate plant height and canopy diameter based on stem diameter measurements. The first studies on the relation between canopy diameter and stem diameter were conducted more than 100 years ago, and since then a number of papers have been carried out involving several species (Santos et al. 2001; Hemery et al. 2005). Among the species adapted to the Caatinga, the only study found in the literature has dealt with cashew trees (Silva et al. 2004).
The objectives of this paper were to evaluate the growth of seven species adapted to the Brazilian SemiArid Region, and to obtain linear regression equations for those species to estimate plant height (y) and canopy diameter $(\mathrm{x})$ from the stem diameter.

\section{Material and methods}

Localization and environmental aspects - The experiment was conducted at the "Rafael Fernandes" Experimental Farm (latitude $5^{\circ} 11^{\prime} \mathrm{S}$, longitude $37^{\circ} 20^{\prime} \mathrm{W}$ and altitude $18 \mathrm{~m}$ ), Mossoró county, Rio Grande do Norte State, Brazil. The mean maximum temperature in the region is between 32.1 and $34.5^{\circ} \mathrm{C}$ and the minimum is between 21.3 and $23.7^{\circ} \mathrm{C}$, with June and July as the coolest months. In view of the low latitude, the mean temperature does not present great annual variations. Since the region is located between the 500 and $700 \mathrm{~mm}$ isohyets, the climate, according to the Köppen system classification, is ranked as type BSwh', that is, very hot with a summer rainy season that extends through the fall. The mean annual evapotranspiration is around $2000 \mathrm{~mm}$ and the mean insolation is 236 hours month $^{-1}$, with the driest months also being the months with the least insolation. The relative humidity is between 60.5 and $79.1 \%$ and the mean monthly wind speed ranges between 2.6 and $5.6 \mathrm{~m} \mathrm{~s}^{-1}$ (Carmo Filho \& Oliveira 1989).

The soil was classified as a Red-Yellow Argisol, according to the Brazilian Soil Classification System (Embrapa 1999) and as a Ferric Lixisol, according to the Soil Map of the World (FAO 1988). The soil analysis indicated $\mathrm{pH}=6.8 ; \mathrm{Ca}=1.80 \mathrm{cmol}_{\mathrm{c}}{ }^{-1} \mathrm{dm}^{-3}$; $\mathrm{Mg}=0.40 \mathrm{cmol}_{\mathrm{c}} \mathrm{dm}^{-3} ; \mathrm{K}=0.10 \mathrm{cmol}_{\mathrm{c}} \mathrm{dm}^{-3} ;$ $\mathrm{Na}=0.01 \mathrm{cmol}_{\mathrm{c}} \mathrm{dm}^{-3} ; \mathrm{Al}=0.00 \mathrm{cmol}_{\mathrm{c}} \mathrm{dm}^{-3} ;$ $\mathrm{P}=25 \mathrm{mg} \mathrm{dm}^{-3}$; Org. Matt. $=1.90 \mathrm{~g} \mathrm{~kg}^{-1}$. The manure analysis gave $\mathrm{pH}$ (water) $=8.1 ; \mathrm{Ca}=4.0 \mathrm{cmol}_{\mathrm{c}} \mathrm{dm}^{-3} ; \mathrm{Mg}$ $=5.5 \mathrm{cmol}_{\mathrm{c}} \mathrm{dm}^{-3} ; \mathrm{K}=1.72 \mathrm{cmol}_{\mathrm{c}} \mathrm{dm}^{-3} ; \mathrm{Na}=$ $1.84 \mathrm{cmol}_{c} \mathrm{dm}^{-3} ; \mathrm{Al}=0.00 \mathrm{cmol}_{\mathrm{c}} \mathrm{dm}^{-3} ; \mathrm{P}=76.7 \mathrm{mg} \mathrm{dm}^{-3}$.

Experimental design and evaluated characteristics - Seven seed-propagated species mesquite (Prosopis juliflora (Sw.) DC.), jucá (Caesalpinia ferrea Mart.), white popinac (Leucaena leucocephala (Lam.) de Wit), mofumbo (Combretum leprosum Mart.), neem (Azadirachta indica A. Juss.), sabiá (Mimosa caesalpiniaefolia Benth.), and tamarind (Tamarindus indica L.) were sowed in January, 2003. The seeds were sown in black plastic bags, $32 \mathrm{~cm}$ tall and $25 \mathrm{~cm}$ in diameter, perforated in their bottom third. The bags were filled with substrate consisting of $1 / 3$ manure and 
2/3 soil. Transplanting was performed in March, 2003, to a soil of the same type. The seedlings were transplanted to pits measuring $60 \mathrm{~cm} \times 60 \mathrm{~cm} \times 60 \mathrm{~cm}$. The species were evaluated in a random block design with four replicates and nine plants per plot. In the analysis of variance for the growth data, the random block design with split-plot was adopted. In this case, tree species were plots and evaluation seasons were considered subplots. Plant height, crown, and stem diameters were evaluated in all plants of each plot, biannually from October/2003 to March/2005. The distance from ground level to the highest point of the crown was considered as plant height. The mean diameter values for the crown or stem, measured in two perpendicular directions, were considered the crown and stem diameters, respectively. Stem diameter was measured at $10 \mathrm{~cm}$ above the ground with a digital caliper rule.

Data analysis - The analysis of variance was made with software developed by Universidade Federal de Viçosa (Ribeiro Júnior 2001). For the regression analysis, the software developed by Jandel (1992) was used. In cases where the intercept coefficient value (a) was non-significant, a new equation was fitted containing only the slope coefficient value (b). A similar procedure was adopted by other authors (Salam \& Abdurazak 2002). Equations whose analysis provided the highest coefficient of determination values $\left(R^{2}\right)$ were considered the best among those that presented regression coefficients different from zero.

\section{Results and discussion}

In terms of plant height, the trees behaved differently during the observation period. This was indicated by the existence of an interaction between species $\times$ ages in the analysis of variance and by the curve type fitted (Tab. 1). In the first two measurements, the trees could be separated into two groups; smaller height trees, represented by mofumbo and tamarind, and greater height trees, represented by the other species evaluated. From this initial division, the greater growth of some species, especially mesquite, and the smaller growth of others, such as tamarind, allowed the group of species evaluated to be further divided into several subgroups, according to plant height. In general, high coefficients of determination were obtained, with the only exception of mesquite.

An interaction between species $\times$ ages was also verified with regard to canopy diameter (Tab. 2).

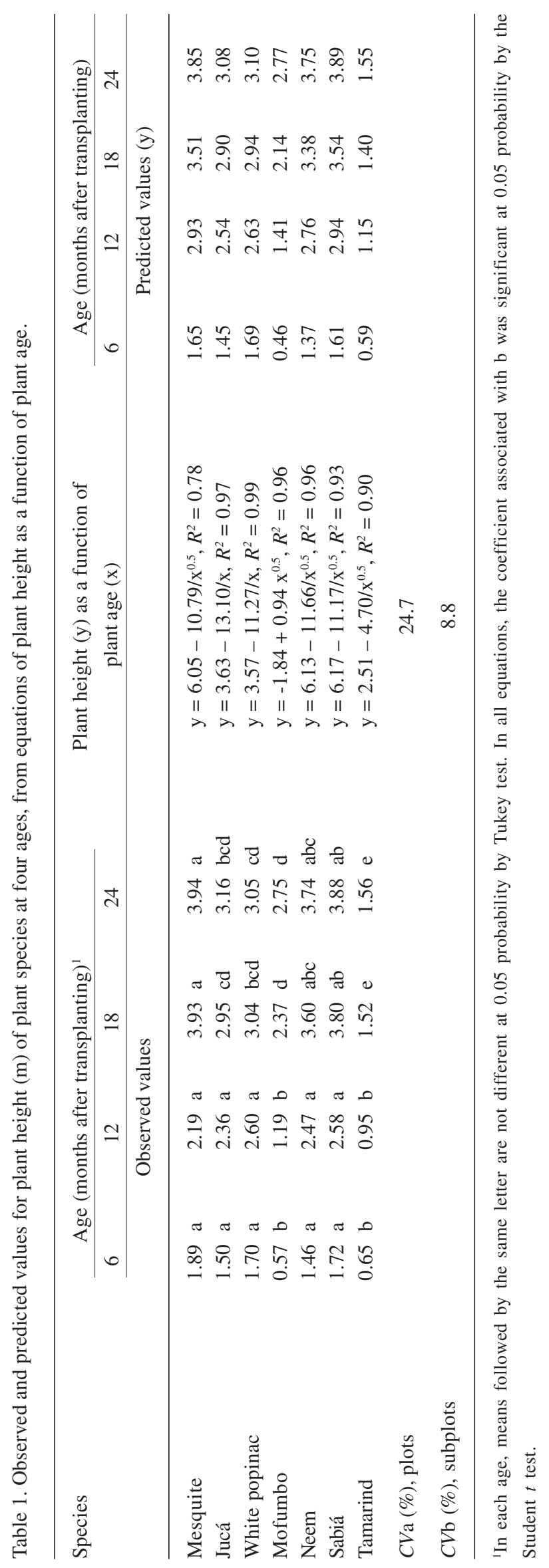




\begin{tabular}{|c|c|c|c|c|c|c|c|c|c|}
\hline \multirow[t]{3}{*}{ Species } & \multicolumn{4}{|c|}{ Age (months after transplanting) ${ }^{1}$} & \multirow{2}{*}{$\begin{array}{l}\text { Conopy diameter }(\mathrm{y}) \text { as a } \\
\text { function of plant age }(\mathrm{x})\end{array}$} & \multicolumn{4}{|c|}{ Age (months after transplanting) } \\
\hline & 6 & 12 & 18 & 24 & & 6 & 12 & 18 & 24 \\
\hline & \multicolumn{4}{|c|}{ Observed values } & & \multicolumn{4}{|c|}{ Predicted values (y) } \\
\hline Jucá & $1.24 \mathrm{~b}$ & $1.86 \mathrm{c}$ & $2.24 \mathrm{~b}$ & $2.68 \mathrm{~b}$ & $\mathrm{y}=-0.17+0.58 \mathrm{x}^{0.5}, R^{2}=1.00$ & 1.25 & 1.84 & 2.29 & 2.67 \\
\hline White popinac & $1.13 \mathrm{~b}$ & $2.34 \mathrm{bc}$ & $2.55 \mathrm{~b}$ & $2.76 \mathrm{~b}$ & $\mathrm{y}^{2}=9.49-49.28 / \mathrm{x}, R^{2}=1.00$ & 1.13 & 2.32 & 2.60 & 2.73 \\
\hline Mofumbo & $0.85 \mathrm{~b}$ & $1.55 \mathrm{~cd}$ & $2.93 \mathrm{~b}$ & $3.44 \mathrm{~b}$ & $\mathrm{y}=-0.10+0.15 \mathrm{x}, R^{2}=0.97$ & 0.80 & 1.70 & 2.60 & 3.50 \\
\hline Neem & $0.80 \mathrm{~b}$ & $1.49 \mathrm{~cd}$ & $2.10 \mathrm{~b}$ & $2.66 \mathrm{~b}$ & $\mathrm{y}=0.22+0.10 \mathrm{x}, R^{2}=1.00$ & 0.82 & 1.42 & 2.02 & 2.62 \\
\hline Sabiá & $2.53 \mathrm{a}$ & $4.18 \mathrm{a}$ & $4.72 \mathrm{a}$ & $5.22 \mathrm{a}$ & $\mathrm{y}=7.86-13.00 / \mathrm{x}^{0.5}, R^{2}=1.00$ & 2.55 & 4.11 & 4.80 & 5.21 \\
\hline Tamarind & $0.43 \mathrm{~b}$ & $0.71 \mathrm{~d}$ & $1.08 \mathrm{c}$ & $1.47 \mathrm{c}$ & $\mathrm{y}=0.05+0.06 \mathrm{x}, R^{2}=0.99$ & 0.41 & 0.77 & 1.13 & 1.49 \\
\hline$C V$ a $(\%)$, plots & & & & & 28.4 & & & & \\
\hline$C V \mathrm{~b}(\%)$, subplots & & & & & 11.5 & & & & \\
\hline
\end{tabular}

${ }^{1}$ In each age, means followed by the same letter are not different at 0.05 probability by Tukey test. In all equations, the coefficient associated with $b$ was significant at 0.05 probability by the Student $t$ test.

Table 3. Observed and predicted values for stem diameter at $10 \mathrm{~cm}$ above ground $(\mathrm{mm})$ of plant species at four ages, from equations of stem diameter as a function of plant age.

\begin{tabular}{|c|c|c|c|c|c|c|c|c|c|}
\hline \multirow[t]{3}{*}{ Species } & \multicolumn{4}{|c|}{ Age (months after transplanting) ${ }^{1}$} & \multirow{2}{*}{$\begin{array}{l}\text { Stem diameter }(y) \text { as a } \\
\text { function of plant age }(x)\end{array}$} & \multicolumn{4}{|c|}{ Age (months after transplanting) } \\
\hline & 6 & 12 & 18 & 24 & & 6 & 12 & 18 & 24 \\
\hline & \multicolumn{4}{|c|}{ Observed values } & & \multicolumn{4}{|c|}{ Predicted values (y) } \\
\hline Mesquite & $30.9 \mathrm{a}$ & $40.0 \mathrm{ab}$ & $69.8 \mathrm{~b}$ & $80.7 \mathrm{bc}$ & $\mathrm{y}=-26.39+21.72 \mathrm{x}^{0.5}, R^{2}=0.93$ & 26.8 & 48.9 & 65.8 & 80.0 \\
\hline Jucá & $18.4 \mathrm{ab}$ & $24.6 \mathrm{bc}$ & $37.9 \mathrm{~cd}$ & $51.9 \mathrm{de}$ & $\mathrm{y}=16.21+0.06 \mathrm{x}^{2}, R^{2}=1.00$ & 18.4 & 24.9 & 35.7 & 50.8 \\
\hline White popinac & $27.8 \mathrm{ab}$ & $38.6 \mathrm{ab}$ & $66.2 \mathrm{~b}$ & $76.2 \mathrm{bc}$ & $\mathrm{y}=9.00+2.88 \mathrm{x}, R^{2}=0.96$ & 26.3 & 43.6 & 60.8 & 78.1 \\
\hline Mofumbo & $14.7 \mathrm{ab}$ & $22.4 \mathrm{bc}$ & $55.5 \mathrm{bc}$ & $65.1 \mathrm{~cd}$ & $\mathrm{y}=-44.58+22.32 \mathrm{x}^{0.5}, R^{2}=0.91$ & 10.1 & 32.7 & 50.1 & 64.8 \\
\hline Neem & $26.9 \mathrm{ab}$ & $39.3 \mathrm{ab}$ & $71.2 \mathrm{ab}$ & $85.3 \mathrm{~b}$ & $\mathrm{y}=3.90+3.45 \mathrm{x}, R^{2}=0.97$ & 24.6 & 45.3 & 66.0 & 86.7 \\
\hline Sabiá & $32.3 \mathrm{a}$ & $44.8 \mathrm{a}$ & $90.0 \mathrm{a}$ & 104.9 a & $\mathrm{y}=-51.96+31.87 \mathrm{x}^{0.5}, R^{2}=0.93$ & 26.1 & 58.4 & 83.3 & 104.2 \\
\hline Tamarind & $9.7 \mathrm{~b}$ & $13.3 \mathrm{c}$ & $25.2 \mathrm{~d}$ & $35.6 \mathrm{e}$ & $\mathrm{y}=6.62+0.05 \mathrm{x}^{2}, R^{2}=0.97$ & 8.4 & 13.8 & 22.8 & 35.4 \\
\hline$C V \mathrm{a}(\%)$, plots & & & & & 31.6 & & & & \\
\hline$C V \mathrm{~b}(\%)$, subplots & & & & & 11.6 & & & & \\
\hline
\end{tabular}

${ }^{1}$ In each age, means followed by the same letter are not different at 0.05 probability by Tukey test. In all equations, the coefficient associated with $\mathrm{b}$ was significant at 0.05 probability by the Student $t$ test. 
Similarly as observed for plant height, the greater growth in canopy diameter of some species, such as mesquite and sabiá, and the smaller growth of others, especially tamarind, determined the formation, at the end of the observation period, of three subgroups instead of those two that existed in the first measurement. For this trait, the coefficients of determination of the fitted equations were all high.

With reference to stem diameter, the species behaved differently in the four measurement seasons (Tab. 3). The differences between them increased as plant age increased. Sabiá and tamarind showed, respectively, the greatest and the smallest stem diameters in all seasons in which this trait was measured. Here again, the coefficients of determination were all high for the fitted equations.

Evaluations involving perennial plant species have demonstrated, as in the present study, differences between themselves in relation to traits intended to evaluate growth, including traits estimated in this work (Heineman et al. 1997; Kumar et al. 1998; Souza et al. 2001). No papers were found in the consulted literature on the joint evaluation of the species herein considered. The results of the present study, however, corroborate papers or observations made for one or more of the species studied here. For example, fast sabiá growth has also been observed by other authors (Almeida et al. 1987). Such fast growth, in association with its proven tolerance to drought, makes sabiá to be considered indispensable in any reforestation program in the Northeastern Region of Brazil, especially in the SemiArid Region (Burity et al. 2000). In this species, the fast increase in stem diameter (Tab. 4) is important, as the species is greatly exploited for the production of stakes. Mesquite is also considered to be droughtresistant and to grow fast, but differently from sabiá, opinions about its cultivation are divergent. Some think it is advantageous because it provides firewood and dune fixation, while others think it is a noxious weed (Pasiecznik et al. 2001). Neem can also be considered a fast-growing species, since it did not differ from the species that presented the greatest growth, at least with regard to plant height (Tab. 2). This species has attracted worldwide attention due to its potential as a source of natural drugs and pesticides harmless to the environment (Mulla \& Su 1999; Joshi \& Lockwood 2000). Recently, the use of leaves of this species was suggested for the production of vermicompost (Gajalakshmi \& Abbasi 2004). Jucá and white popinac, on the other hand, showed intermediate growth (Tab. 2 to 4 ), in agreement with observations made by other authors (Kumar et al. 1998; Souza et al. 2001). No information was found in the consulted literature on mofumbo growth, but some authors (Reena \& Bagyaraj 1990) underlined the slow growth of tamarind, as demonstrated in the present study.

In the fitted regression equations, the intercept coefficient was not significant in a few cases only, but the slope coefficient was significant for all species (Tab. 4). In general, the coefficients of determination were high. This is important because measuring stem diameter, which requires a single person, is much easier than measuring canopy diameter, which requires two people, or measuring plant height, especially with larger plants. In addition, stem diameter can be measured with high precision and very quickly using digital caliper rules.

The results obtained in the present study agree, in some aspects, with those obtained by other authors for cashew tree (Anacardium occidentale L.), also a species adapted to the Semi-Arid conditions. Regression equations were fitted (Salam \& Abdurazak 2002) considering a two-year period for 18 cultivars, when the crop was 11 and 13 years old. In the first evaluation, only the intercept coefficient was significant, but in the second evaluation both coefficients were significant. According to those authors, the importance of the intercept coefficient decreases, while the importance of the slope coefficient increases as the plant grows. In other words, in young cashew trees, plant height is less related to canopy diameter. Other authors (Silva et al. 2004) verified that intercept coefficient importance was more dependent on the cultivar studied than on plant age. In the present study, the importance of the intercept coefficient was dependent upon the species evaluated and also on the trait used as dependent variable. Obviously, using equations of the type $y=b x$ is much simpler than using equations of the type $y=a+b x$. It is worthwhile to remember that higher coefficient of determination values could have been obtained with other more complex equations, but the aim of the present study was to obtain linear equations to facilitate predictions. Incidentally, the coefficients of determination here obtained had a similar or even higher magnitude than those obtained in similar studies conducted by other authors (Pretzsch et al. 2002). In their studies, the coefficients of determination ranged from 0.48 to 0.84 , depending on the species studied. It is important to highlight that the use of models published for a given species based on data obtained in a region different than the one at which the model was obtained could 
Table 4. Values for parameters a and $\mathrm{b}$, and coefficients of determination of linear regression equations for plant height (PH, $\mathrm{m})$ and canopy diameter $(\mathrm{CD}, \mathrm{m})$ estimation from the stem diameter $(\mathrm{SD}, \mathrm{mm})$ of seven species adapted to the Brazilian Semi-arid Region.

\begin{tabular}{lcccccc}
\hline Species $^{1}$ & \multicolumn{3}{c}{$\mathrm{PH}=\mathrm{f}(\mathrm{SD})$} & & \multicolumn{3}{c}{$\mathrm{CD}=\mathrm{f}(\mathrm{SD})$} \\
\cline { 2 - 4 } & $\mathrm{a}$ & $\mathrm{b}$ & $R^{2}$ & & $\mathrm{~b}$ & $R^{2}$ \\
\hline Mesquite & 0.66 & 0.04 & 0.92 & 1.66 & 0.04 & 0.83 \\
Jucá & 0.95 & 0.04 & 0.82 & 0.63 & 0.04 & 0.77 \\
White popinac & 1.28 & 0.03 & 0.76 & 0.80 & 0.03 & 0.70 \\
Mofumbo & 0.00 & 0.04 & 0.91 & 0.00 & 0.05 & 0.90 \\
Neem & 0.73 & 0.04 & 0.92 & 0.00 & 0.03 & 0.92 \\
Sabián & 1.05 & 0.03 & 0.90 & 2.12 & 0.03 & 0.71 \\
Tamarind & 0.47 & 0.03 & 0.76 & 0.00 & 0.04 & 0.86 \\
\hline
\end{tabular}

${ }^{1}$ All coefficients different from zero were significant at 0.05 probability by the Student $t$ test.

result in erroneous predictions, as has been warned by other authors (Condés \& Sterba 2005).

Therefore, it can be concluded that at the end of the measurement period, Prosopis juliflora and Mimosa caesalpiniaefolia showed the highest stem diameter and plant height values, respectively, and both showed the highest canopy diameter. In the equations to estimate plant height from the stem diameter the value of the coefficient of determination $\left(R^{2}\right)$ ranged from 0.76 (Tamarindus indica and Leucaena leucocephala) to 0.92 (Prosopis juliflora and Azadirachta indica). In the equations that allowed to estimate the crown diameter from the stem diameter the $R^{2}$ value ranged from 0.70 (Leucaena leucocephala) to 0.92 (Azadirachta indica).

\section{Acknowledgment}

The authors thank Conselho Nacional de Desenvolvimento Científico e Tecnológico (CNPq) for the financial support.

\section{References}

Abebe, T. 1994. Growth performance of some multipurpose trees and shrubs in the semi-arid áreas of southern Ethiopia. Agroforestry Systems 26(2): 237-248.

Almeida, R.T.; Freire, V.F. \& Vasconcelos, I. 1987. Efeitos da interação Glomus macrocarpum, Rhizobium sp. e níveis crescentes de fosfato de rocha sobre o desenvolvimento de mudas de sabiá (Mimosa caesalpiniaefolia Benth.) e de leucena (Leucena leucocephala (Lam.) de Wit). Ciência Agronômica 18(1): 131-136.

Brasil. 2001. Ministério do Meio Ambiente. Uso sustentável dos recursos florestais e conservação da biodiversidade da Caatinga. Brasília, Ministério do Meio Ambiente.
Burity, H.A.; Lyra, M.C.C.P.; Souza, E.S.; Mergulhão, A.C.E.S. \& Silva, M.L.R.B. 2000. Efetividade da inoculação com rizóbio e fungos micorrízicos arbusculares em mudas de sabiá submetidas a diferentes níveis de fósforo. Pesquisa Agropecuária Brasileira 35(5): 801-807.

Carmo Filho, F. \& Oliveira, O.F. 1989. Mossoró: um município do semi-árido nordestino. Mossoró, Fundação Guimarães Duque/ESAM. (Coleção Mossoroense, Série B, n. 672).

Cervantes, V.; Arriaga, V.; Meave, J. \& Carabias, J. 1998. Growth analysis of nine multipurpose woody legumes native from southern México. Forest Ecology and Management 110(1-3): 329-341.

Condés, S. \& Sterba, H. 2005. Derivation of compatible crown width equations for some important tree species for Spain. Forest Ecology and Management 217(2-3): 203-218.

Deans, J.D.; Diagne, O.; Nizinski, J.; Lindley, D.K.; Seck, M.; Ingleby, K. \& Munro, R.C. 2003. Comparative growth, biomass production, nutrient use and soil amelioration by nitrogen-fixing tree species in semiarid Senegal. Forest Ecology and Management 176(1-3): 253-264.

Embrapa. 1999. Centro Nacional de Pesquisa do Solo. Sistema brasileiro de classificação de solos. Brasília, Serviço de Produção de Informação.

FAO. 1988. Soil map of the world; revised legend. Rome, UNESCO.

Francelino, M.R.; Fernandes Filho, E.I.; Resende, M. \& Leite, H.G. 2003. Contribuição da caatinga na sustentabilidade de projetos de assentamentos no sertão norte-riograndense. Revista Árvore 27(1): 79-86.

Gajalakshmi, S. \& Abbasi, S.A. 2004. Neem leaves as a source of fertilizer-cum-pesticide vermicompost. Bioresource Technology 92(3): 291-296.

Heineman, A.M.; Otieno, H.J.O.; Mengich, E.K. \& Amadalo, B.A. 1997. Growth and yield of eight agroforestry tree species in line plantings in Western Kenya and their effect on maize yields and soil properties. Forest Ecology and Management 91(2): 103-135. 
Hemery, G.E.; Savill, P.S. \& Pryor, S.N. 2005. Applications of the crown diameter-stem diameter relationship for different species of broadleaved trees. Forest Ecology and Management 215(1-3): 285-294.

Jandel. 1992. Jandel TBLCURVE. Table Curve 3.0. Corte Madera, Jandel Scientific.

Joshi, P.C. \& Lockwood, J.A. 2000. Antifeedent effect of aqueous extract of neem (Azadirachta indica A. Juss.) leaves on Oxya velox F. (Orthoptera: Arididae). Journal of Agricultural and Urban Entomology 17(1): 21-26.

Kumar, B.M.; George, S.J.; Jamaludheen, V. \& Suresh, T.K. 1998. Comparison of biomass production, tree allometry and nutrient use efficiency of multipurpose trees grown in woodlot and silvopastoral experiments in Kerala, India. Forest Ecology and Management 112(1-2): 145-163.

Leary, R.A.; Nimerfro, K.; Holdaway, M.; Brand, G.; Burk, T.; Kolka, R. \& Wolf, A. 1997. Height growth modeling using second order differential equations and the importance of initial height growth. Forest Ecology and Management 97(2): 165-172.

Mulla, M.S. \& Su, T. 1999. Activity and biological effects of neem products against arthropods of medical and veterinary importance. Journal of the American Mosquito Control Association 15(1): 133-152.

Pasiecznik, N.M.; Felker, P.; Harris, P.J.C.; Harsh, L.N.; Cruz, G.; Tewari, J.C.; Cadoret, K. \& Maldonado, L.J. 2001. The Prosopis juliflora-Prosopis pallida complex. Coventry, HDRA.
Pretzsch, H.; Biber, P. \& Dursky, J. 2002. The single tree-based stand simulator SILVA: construction, application and evaluation. Forest Ecology and Management 162(1): 3-21.

Reena, J. \& Bagyaraj, D.J. 1990. Growth stimulation of Tamarindus indica by selected VA mycorrhizal fungi. World Journal of Microbiology and Biotechnology 6(1): 59-63.

Ribeiro Júnior, J.I. 2001. Análises estatísticas no SAEG. Viçosa, Universidade Federal de Viçosa.

Salam, M.A. \& Abdurazak, M.P. 2002. Regression model for tree height in cashew. Journal of Plantation Crops 30(1): 62-63.

Sampaio, E.S.V.B.; Salcedo, I.H. \& Silva, F.B.R. 1995. Fertilidade dos solos do semi-árido. Pp. 51-71. In: J.R. Pereira \& C.M.B. Faria (eds.). Fertilizantes: insumo básico para a agricultura e combate à fome. Petrolina, EMBRAPA-CPATSA/SBCS.

Santos, J.; Paula Neto, F.; Higuchi, N.; Leite, H.G.; Souza, A.L. \& Vale, A.B. 2001. Modelos estatísticos para estimar a fitomassa acima do nível do solo da floresta tropical úmida da Amazônia Central. Revista Árvore 25(4): 445-454.

Silva, K.M.B.; Silva, P.S.L. \& Almeida, F.A.G. 2004. Regressions equations for plant height estimation in cashew trees. Revista Ceres 51(295): 405-409.

Souza, P.A.; Venturin, N.; Macedo, R.L.G.; Alvarenga, M.I.N. \& Silva, V.F. 2001. Estabelecimento de espécies arbóreas em recuperação de área degradada pela extração de areia. Cerne 7(1): 43-52. 